\title{
Anatomical Structure of the Roots of Barley.
}

\author{
BY \\ VIOLET G. JACKSON, M.SC. \\ (Rothamsted Experimental Station.) \\ With twelve Figures in the Text.
}

A BARLEY plant, if carefully removed from the soil when about A six to eight weeks old, generally shows two distinct types of roots. The bulk of the underground system consists of long roots which branch throughout almost their entire length, but there are in addition a certain number of 'unbranched' roots. Most of these spring from one of the nodes above the grain and are therefore of later origin than the branched roots, which spring from the grain itself. They are of a very waxen white appearance and attain a length of several inches without giving off any laterals, but ultimately they branch and seem to approximate to the general root system.

The occurrence and behaviour of these white ' unbranched ' roots were studied at Rothamsted in the summer of 1920 , and material obtained then was preserved with a view to ascertaining whether there existed any difference between the anatomical structure of the branched and the unbranched type of root. Material was also obtained from a series of experiments in which barley was grown in water cultures. Very distinct white 'unbranched' roots are found in water cultures when the plants are removed from their solutions at the conclusion of the experiment, somewhat before maturity is reached. In addition to their white colour, 'unbranched' roots can be distinguished from branched roots by their greater thickness and by a much larger number of root-hairs. These latter are particularly noticeable in water cultures, where there is considerably less abrasion than occurs in the soil, but even in soil, if the plants are washed out as described in a previous paper, ${ }^{1}$ it is always difficult to free the white 'unbranched ' roots from the tiny soil particles which adhere very closely along the whole length of the root. In a branched root, this closely adhering soil is only found in the region immediately behind the root-tip, presumably where the root-

1 Brenchley, W. E., and Jackson, V. G.: Root Development in Barley and Wheat under Different Conditions of Growth. Ann. Bot., vol. xxxv, pp. 533-556, I92r.

[Annals of Botany, Vol. XXXVI. No. CXLI. January, 1922.] 
22 Fackson.-Anatomical Structure of the Roots of Barley.

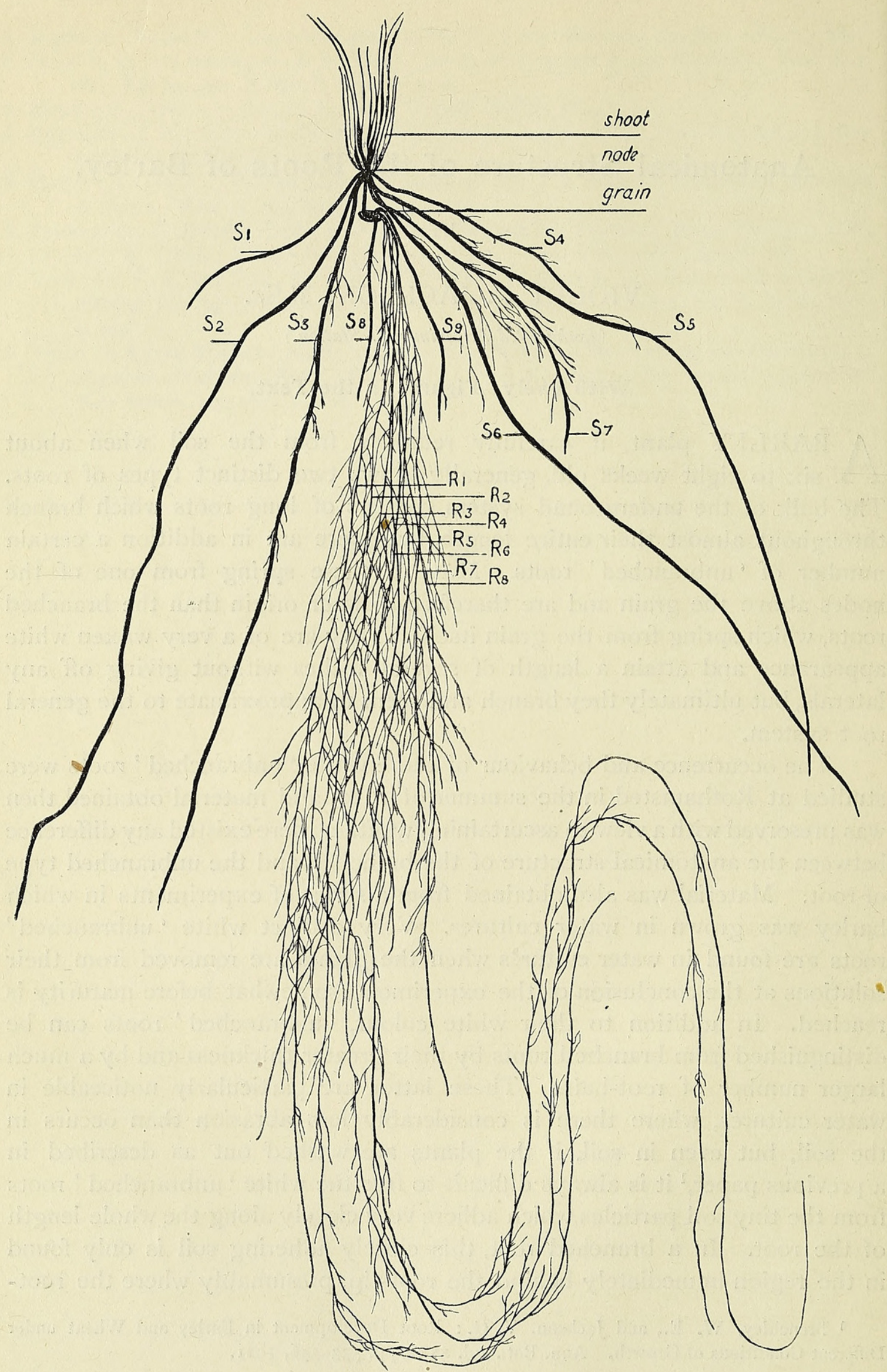

FIG. I. Barley Plant, Drawn from actual specimen, $\frac{1}{2}$ natural size. $\mathbf{R}_{1}-\mathrm{R}_{8}=$ branched roots ; $\mathrm{S}_{1}-\mathrm{S}_{9}=$ ' unbranched' roots. 
hairs have not been rubbed away. This fact has been corroborated by examination of the washed roots under the binocular microscope, whereby the existence of abundant root-hairs from the tip of the 'unbranched' roots right up to their point of origin is made perfectly clear, while in the branched roots hairs are found only for a short distance behind the roottips of the main roots and their lateral branches.

The general appearance of the root system of a plant bearing typical branched and 'unbranched' roots is shown in Fig. $I$. In this case there are two short 'unbranched' roots, $S_{8}$ and $S_{y}$, coming off from the grain, though they do not arise from quite the same point as the typical branched roots, $R_{1}-R_{8}$, of the primary root system. The majority of the 'unbranched' roots, $S_{1}-S_{7}$, spring from a node half an inch above the grain. These roots exhibit various stages of development, from the totally unbranched type $S_{1}$ to the type $S_{7}$ which is still markedly thicker than any of the roots of the primary system, but also bear a good number of laterals. Careful study of the literature on roots has failed to reveal any work on the anatomy or on the functions of these ' unbranched' roots, although the phenomena of ' white roots' is thoroughly well known to the farmer. There is undoubtedly a connexion between the tillering of a plant and its formation of ' unbranched' roots. From a series of pot cultures in which barley was grown, two plants were washed out each week and their root systems examined. Tillering was observed in all the plants just after the first 'unbranched' roots had appeared. This is also found to be the case in winter-sown wheat and oats growing in the field. During the winter the plants are growing very little, but in the spring they begin to push forward, and if a plant just starting to tiller is examined it is found that white 'unbranched' roots are practically always present. These roots appear also in the field barley, but this being a spring-sown crop the 'unbranched ' roots appear at a much earlier stage in the plant's history than in either wheat or oats. That farmers recognize the existence and importance of these ' unbranched' roots is clear from the general practice of horse-hoeing a wheat crop until the 'change of root', which is really the formation of the white roots. ${ }^{1}$ After this has happened it is considered dangerous to horse-hoe, as it would probably involve injury to the newly-formed roots, most of which it must be remembered are nearer the surface of the soil than are the primary roots, since they spring from the node above the grain.

The present paper embodies the results obtained from an anatomical investigation of the two types of roots as found in barley plants grown in soil and in water cultures.

1 The term 'change of root' seems to be of general occurrence among farmers, but no reference to it has been traced in any of the books on agricultural practice. 


\section{ANATOMY OF BRANCHED Roots.}

Young roots. A transverse section of a young barley root examined seven days after sowing, when the root was about $I$ in. in length, presents the appearance shown in Fig. 2. The middle of the root is occupied by a kind of duct bordered by thin-walled cells. The endodermis bounding the stele is distinguishable as a row of tangentially elongated cells, with their walls as yet unthickened. Immediately within the endodermis lies the pericycle, consisting of radially elongated cells, the continuity of which is

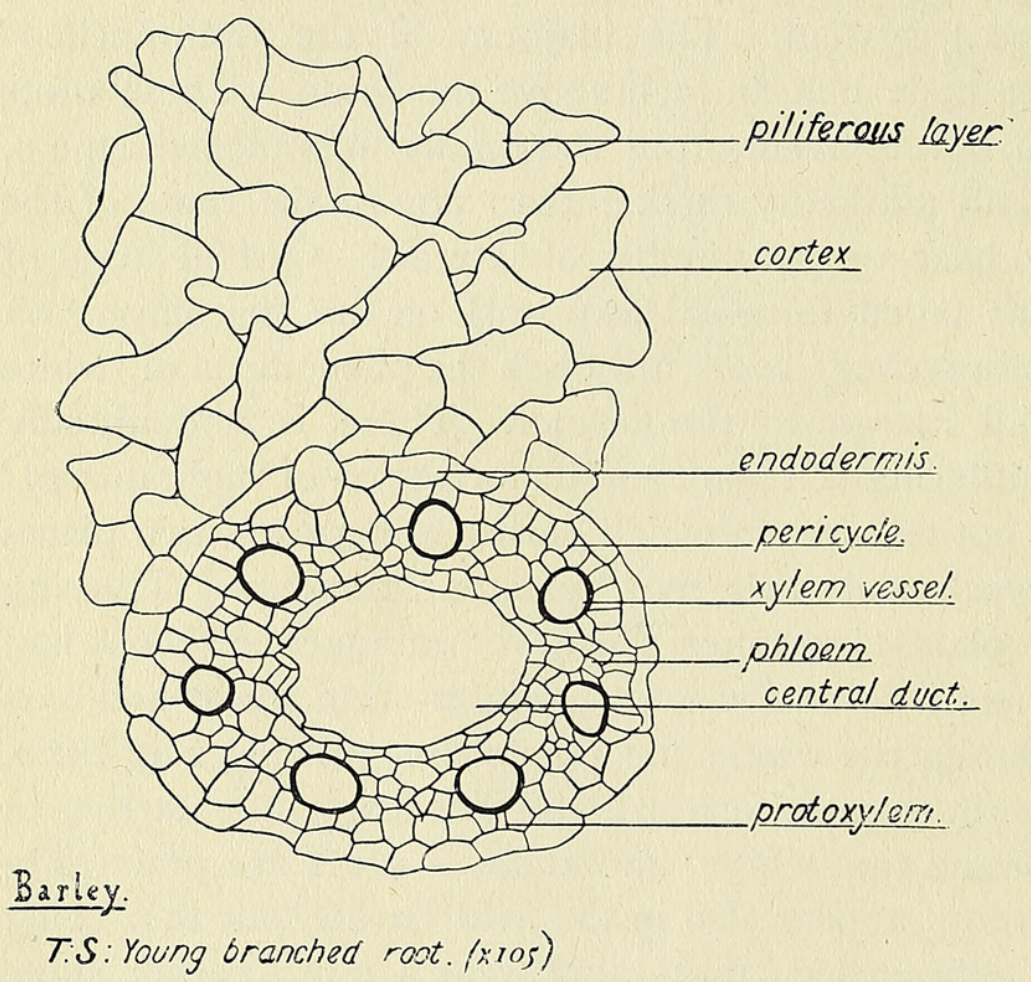

FIG. 2. broken opposite each of the seven xylem groups, where the protoxylem elements abut directly on the endodermis. In addition to the smaller cells of the protoxylem each xylem group contains one large vessel. Alternating with the xylem are the phloem groups, the cells of which are at this stage not easily distinguishable from the rest of the thinwalled ground tissue. Outside the endodermis are four to six layers of large thinwalled cortical cells, bounded by the piliferous layer. The endodermis and all the tissues within it consist of cells packed tightly together, so that no intercellular spaces occur. The same is true for the piliferous layer, but in the cortex small spaces do occur between the cells. These spaces are not entirely due to shrinkage as they are found in fresh material.

Intermediate stage between a young and an old root. A root slightly older than that shown in Fig. 2 shows essentially the same structure, the chief difference being in the pericycle and endodermis, where the cells show signs of thickening. In the pericycle this thickening affects the whole cell wall, but in the endodermis it affects chiefly the inner and radial walls, and it is most noticeable in the cells lying in the zone between the xylem groups. This seems to suggest the formation, at least in the comparatively young roots, of passage cells, as described for Allium and various other plants by 
Haberlandt, ${ }^{1}$ where the endodermal cells opposite the protoxylem remain unthickened and serve as the connecting link between the central cylinder and the cortical parenchyma.

Fully developed roots. Fig. 3 shows the appearance of a transverse section of an old root. The stele here consists of a strongly marked cylinder of much-thickened tissue, and the central duct is bounded by a thick wall and closely resembles a xylem vessel. Such an axile vessel occupying the centre of the root is described by Haberlandt ${ }^{2}$ for the primary roots of Graminaceae and certain other Monocotyledons, and by Kroemer ${ }^{3}$ for Zea Mais, but is not mentioned by Jeffrey, ${ }^{4}$ who states that for the 'mass of monocotyledonous roots' the 'central region of the root is occupied by a well-marked pith'. The number of xylem groups seem to be typically from six to eight; in the root shown in Fig. 3 there are seven groups each containing one large vessel, and alternating with seven groups of phloem, all the intervening tissues consisting of thickened cells.

The endodermis is exceptionally thick-walled, a condition which appears constantly throughout the old branched rcots. This much-thickened endodermis is a characteristic of several monocotyledonous plants.

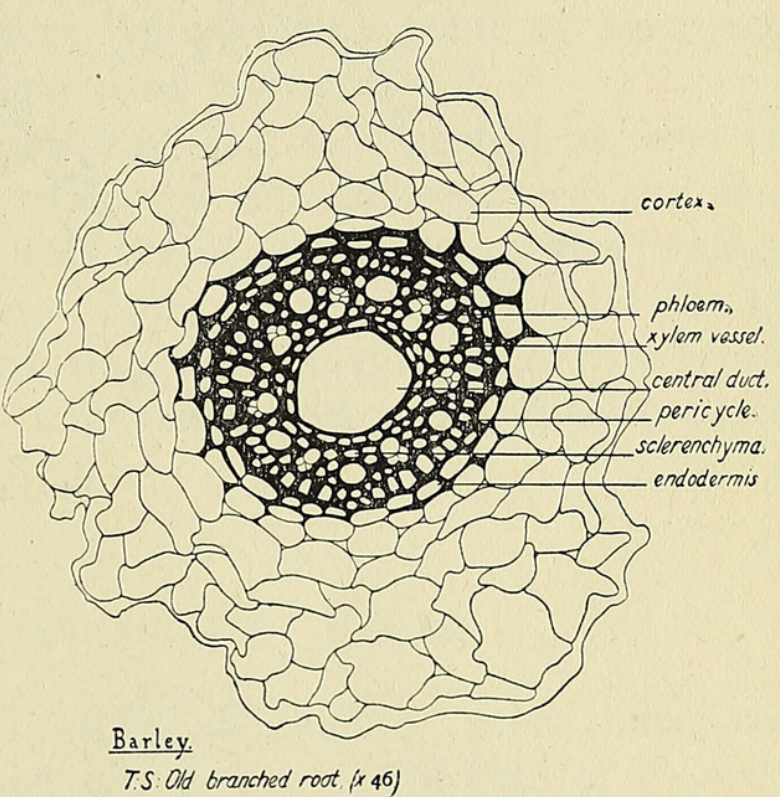

FIG. 3.

It is illustrated for Allium by Haberlandt, ${ }^{1}$ for Zea Mais by Kroemer, ${ }^{3}$ for Oryza by Nägeli and Leitgeb, ${ }^{5}$ and for Dracaen $a$ by Lindinger. ${ }^{6}$ Sections taken at different levels through a branched root $28 \mathrm{in}$. in length reveal the stages shown in Fig. 2 and 3. Immediately behind the root-tip the structure is like that of the young root in Fig. 2, while in the middle portion of the root and near the grain the thickened stele of Fig. 3 is found.

A longitudinal section of an old root shows that the central duct is

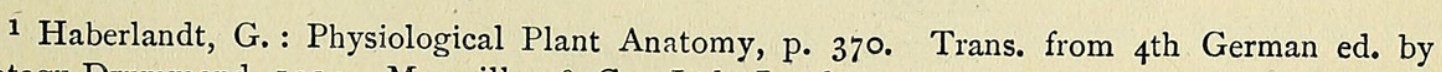
Montagu Drummond, I9 I 4. Macmillan \& Co., Ltd., London.

2 Loc. cit.

3 Kroemer, Karl : Wurzelhaut, Hypodermis und Endodermis der Angiospermenwurzel. Bibliotheca Botanica, Stuttgart, I903, Heft 59, pp. i 5 I, 6 Taf.

4 Jeffrey, Edward Charles: The Anatomy of Woody Plants, p. I 58 . Univ. of Chicago, I9I7.

5 Nägeli, C., and Leitgeb, H. : Entstehung und Wachstum der Wurzeln. Beiträge zur wissenschaftlichen Botanik, Heft iv, pp. 73-160, Taf. xi-xxi.

6 Lindinger, L.: Monokotylenwurzel. Bot. Centralbl., Jena, Beiheft I9, Abt. I, I905, pp. $32 \mathrm{I}-58$. 
of the nature of a vessel with scalariform thickening. The transverse septa of the cells forming the vessel are still present and appear as very thin parenchymatous walls. On either side of the central duct lie several rows

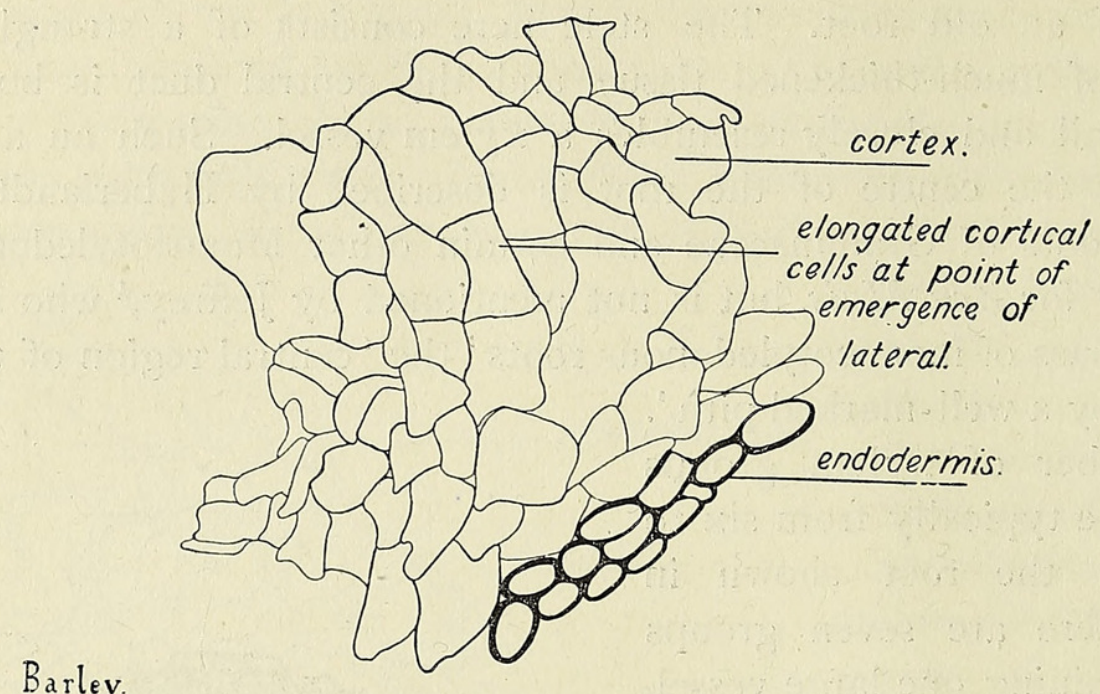

Barley:

T.S: Root through point of

emergence of lateral. (a)

(branched type.) (XIIO)

FIG. 4.

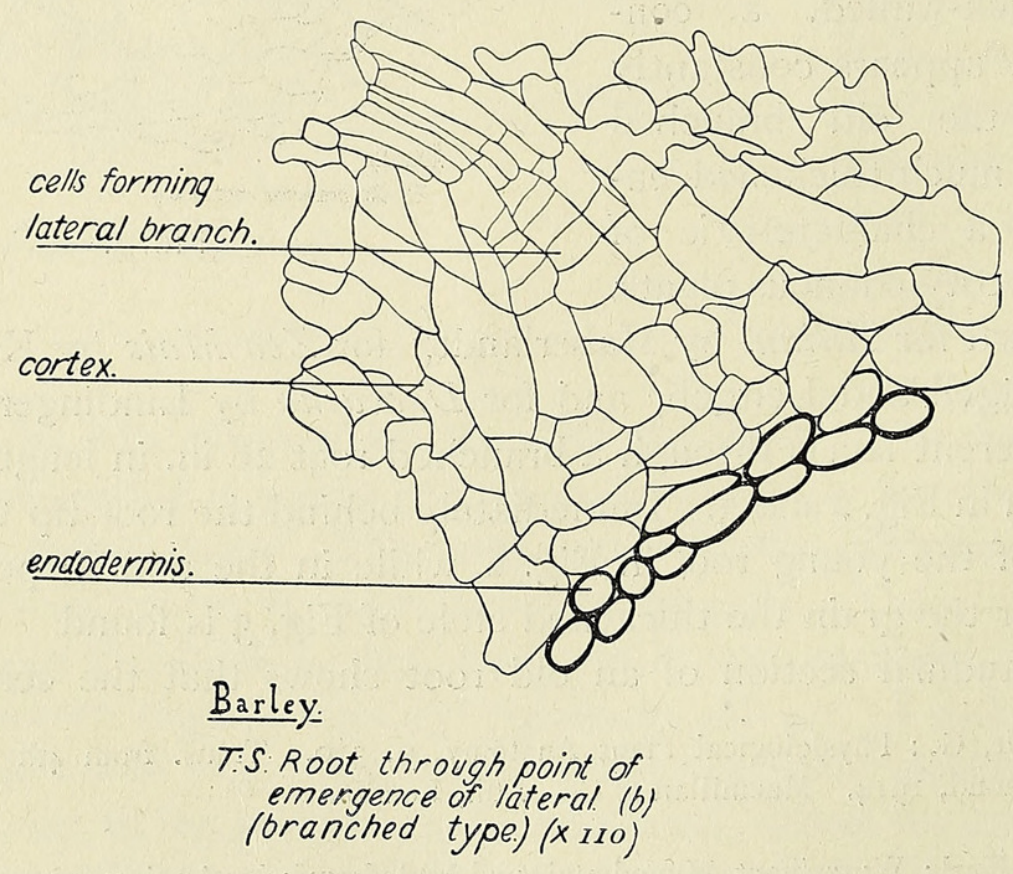

FIG. 5 .

of fibrous cells with pointed ends. Among these are the vessels of the xylem groups, which are generally spirally thickened. Outside this group of cells lie the pericycle and endodermis, which appear as comparatively 
thin-walled cells with square ends, and these are separated from the piliferous layer by the parenchymatous cells of the cortex. The xylem and phloem lie along different radii, therefore a longitudinal section passing through the srylem does not pass through the phloem, so that phloem tissue does not appear in this section.

These primary roots emerge from the grain, and soon reach a length of about 5 in., when they begin to branch freely. The origin of these lateral branches is in some sections shown to be a group of meristematic cells abutting on the endodermis. These cells are full of cell contents and take up any stain very readily. In this condition they resemble the formation of lateral roots in Oryza, as described by Nägeli and Leitgeb. ${ }^{1}$ The meristematic stage is, however, soon over; the lateral root grows out, and most frequently adjacent sections through the point of emergence present the appearance shown in Figs. 4 and 5.

Branched roots are found coming from the node as well as from the grain. Those from the grain are present in the embryo itself and form the primary root system, but those from the node are adventitious in origin. The structure, however, is the same, both for the primary and for the adventitious roots, and in each case transverse sections show the typical thick-walled encodermis and single large axile duct surrounded by muchthickened tissue.

\section{Anatomy of 'Unbranched' Roots.}

Young root. The structure of the 'unbranched' roots differs considerably from that of the branched type. The appearance of a section of a typical young ' unbranched' root is illustrated in Fig. 6. At this stage the whole of the stelar tissue is thin-walled; the central region consists of a core of parenchymatous cells traversed by several large ducts arranged in a circle. In this case six ducts are present, but the number varies for different roots. The xylem and phloem are not yet differentiated, so that outside the circle of ducts lie three or four rows of parenchymatous cells similar to those of the central core. These are bounded by the pericycle, which is distinguishable by its radially elongated cells. The cells of the endodermis are elongated tangentially, and are thus distinguished from the pericycle on the inside and from the cortex on the outside. Eight or nine rows of parenchymatous cells form the cortex, and these are bounded by the thin-walled cells of the piliferous layer.

Intermediate stage between a young and an old root. The structure of a slightly older root is shown in Fig. 7, which illustrates a section taken at a point about half an inch behind the tip of an 'unbranched' root three 
inches in length. The central region of the stele consists of thin-walled parenchyma, and in this root four large ducts are present, two of which are almost completely divided into two separate cavities, so that in the older part of the root six fully developed ducts are found. The xylem groups, each containing one large thickened vessel, are arranged in a circle outside that formed by the ducts. They are separated by thin-walled parenchyma,

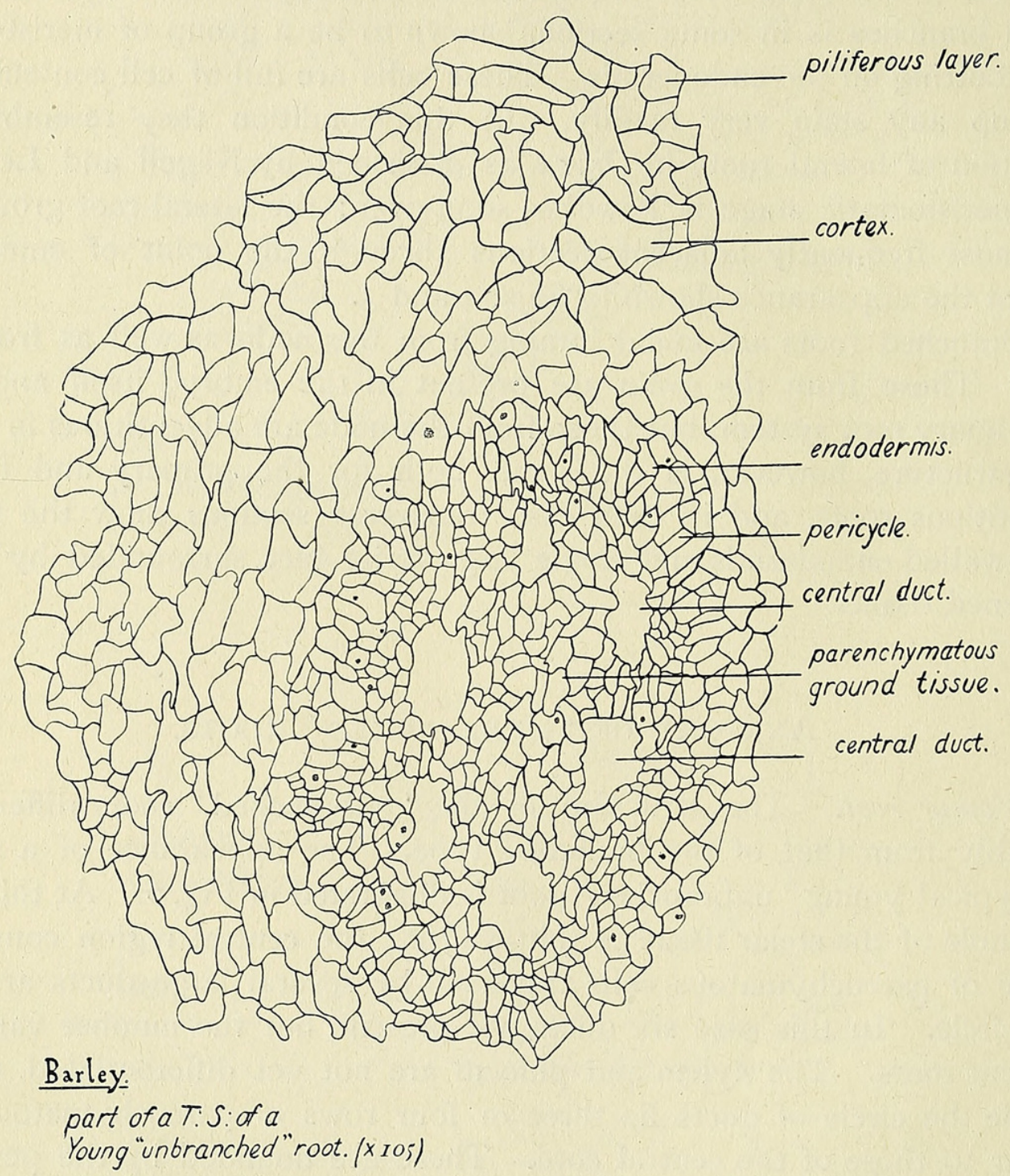

FIG. 6.

the phloem at this stage not being differentiated from the rest of the ground tissue. The pericycle consists of typical radially elongated, and the endodermis of tangentially elongated cells, but in neither layer are any of the cell walls thickened. The cortex is composed of about seven rows of large parenchymatous cells, of which only the inner five rows are shown in the figure. The piliferous layer bounding the cortex also consists of parenchymatous cells rather elongated in the radial direction.

Fully developed roots. A still older root presents the appearance 
shown in Fig. 8. In this case the central part of the stele is traversed by four large ducts separated from each other by thickened cells, but the actual boundary wall of each duct remains thin. Each xylem group contains one large vessel situated on the inner side of the protoxylem elements, and the groups are separated by small parenchymatous cells, among which the phloem cells are not easily distinguishable. The pericycle is composed of cells elongated radially and thickened uniformly on all the walls. Its continuity is interrupted opposite each of the xylem groups where the protoxylem elements abut directly on the endodermis. Here again passage cells occur, for the endodermis cells adjoining the

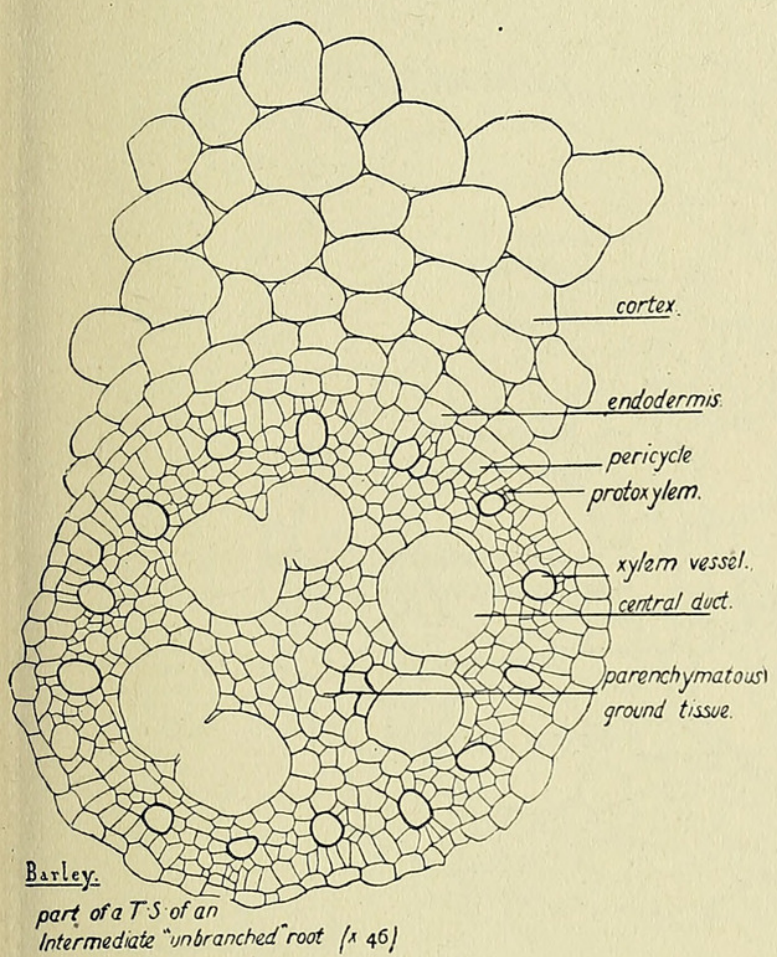

FIG. 7 .

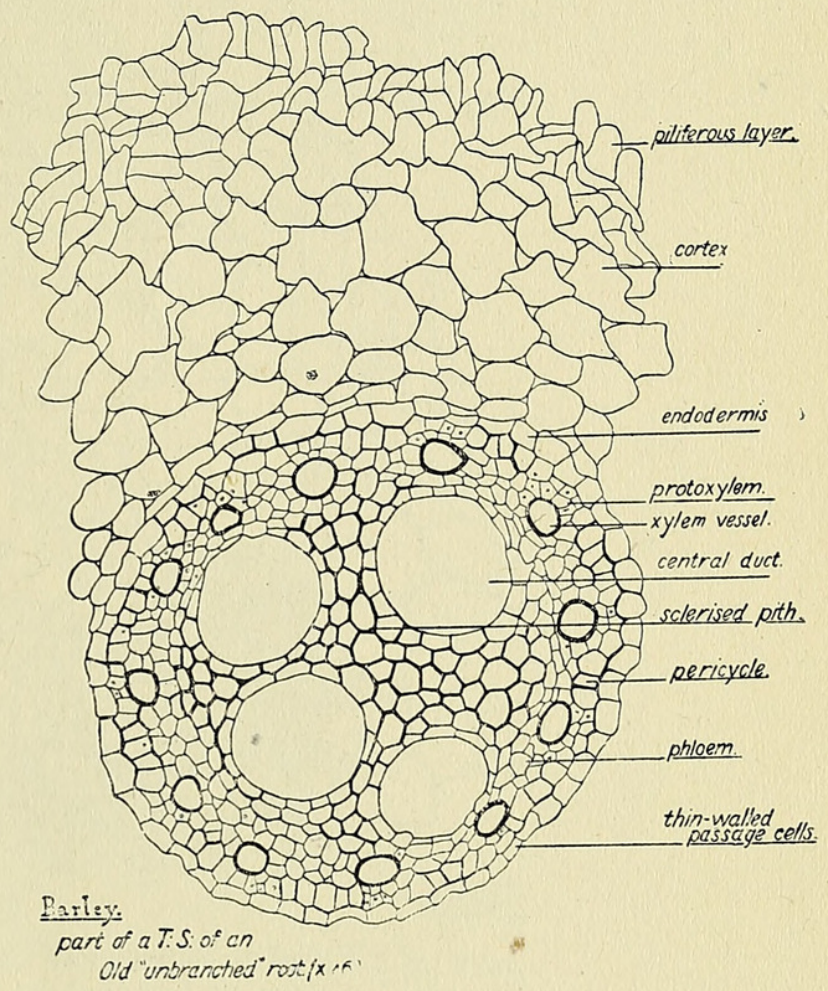

FIG. 8.

protoxylem elements are entirely unthickened, whereas thickening does occur on the radial walls of some of the other endodermis cells. Outside the endodermis are six to eight rows of large parenchymatous cortical cells, bounded by a well-marked piliferous layer.

A longitudinal section of an 'unbranched' root shows that the ducts consist of wide elongated parenchymatous cells, the transverse septa being of the same thickness as the longitudinal walls. When two ducts appear in the section they are separated by several rows of cells, some of which have square, while others have pointed end-walls. The former are the thin-walled cells on the outer edge of the central stelar tissue, while the latter are the sclerized cells of the actual centre. The outer edge of the duct is bounded by a band of parenchymatous cells with square end- 
walls, and among these occur typical spiral and scalariform vessels. This layer of cells is bounded by the thin-walled elements of the pericycle and endodermis, and outside these are the parenchymatous cells of the cortex and of the piliferous layer.

Incipient laterals are present in a typically 'unbranched' root. This is shown in Fig. 9, where the continuity of both the pericycle and the endodermis is entirely broken by a group of meristematic cells in process of forming a lateral branch. This condition is of frequent occurrence and shows up very clearly, as the meristematic cells readily take up the stain.

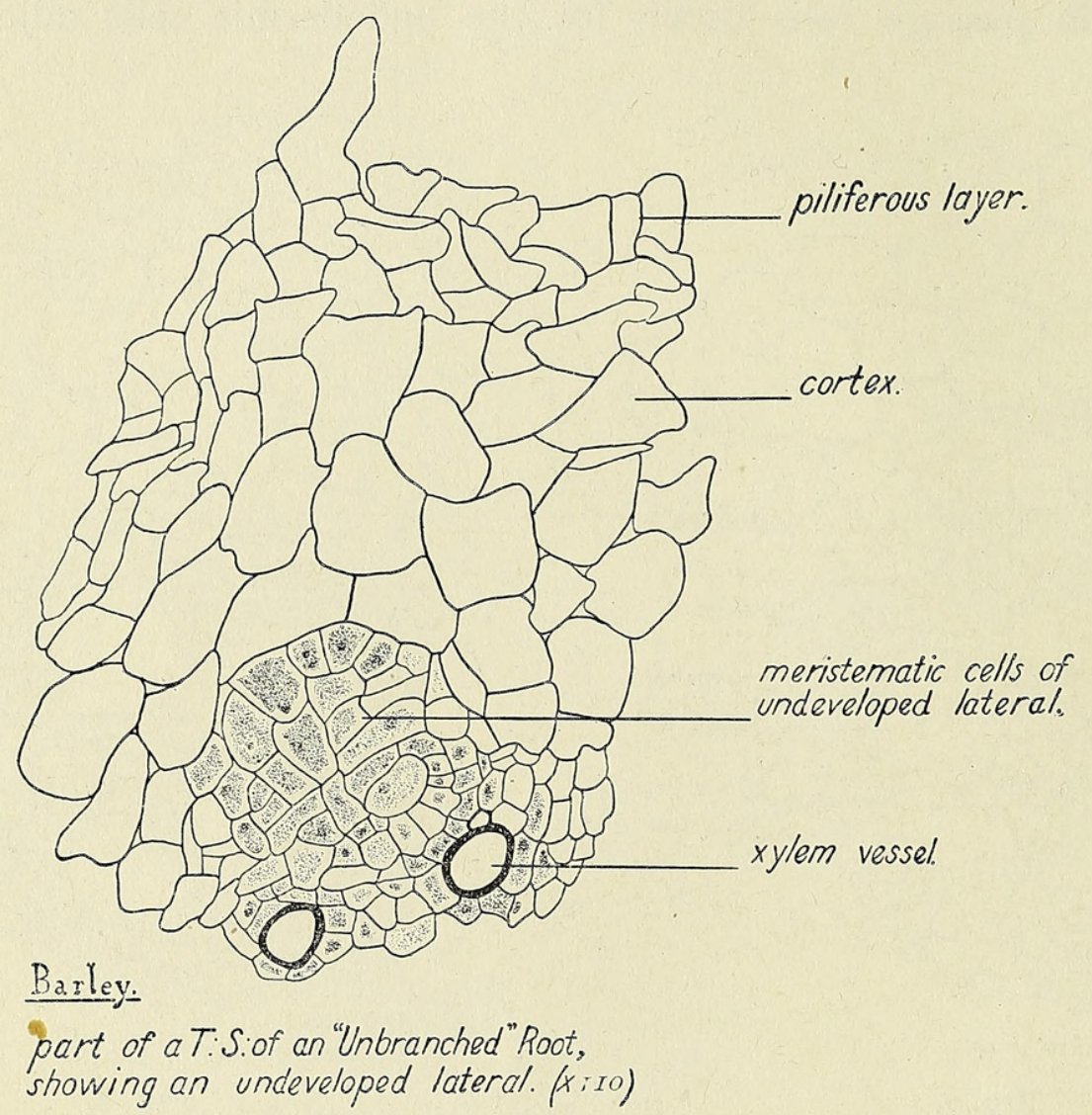

FIG. 9.

It closely resembles the appearance depicted by Nägeli and Leitgeb ${ }^{1}$ for the development of lateral roots in Oryza. These incipient roots remain dormant in their meristematic condition for some time, and only push out when the root is changing from the 'unbranched' to the branched type.

The 'unbranched' roots from the grain are also adventitious, and on sectioning them it is found that their structure is strictly comparable with that of the 'unbranched' roots from the node, a typical section showing a stele with characteristic parenchymatous central region and three ducts.

Development of roots from 'unbranched' into branched type. The ultimate fate of these 'unbranched' roots is that they give off laterals and

\footnotetext{
1 Nägeli, C., and Leitgeb, H. : loc. cit.
} 
approximate more and more to the branched type. At the same time the internal anatomy undergoes certain changes. Fig. Io represents a section of a root of this transition type. The most noticeable feature is the increased development of thickened cells in the central tissue of the stele. The endodermis is also thickened, though not to such a great extent as in the typical branched root. The only cells which are still thin-walled are those of the pericycle and those between the several xylem groups. The phloem cells also become more differentiated and assume the appearance of the corresponding tissue in the branched roots.

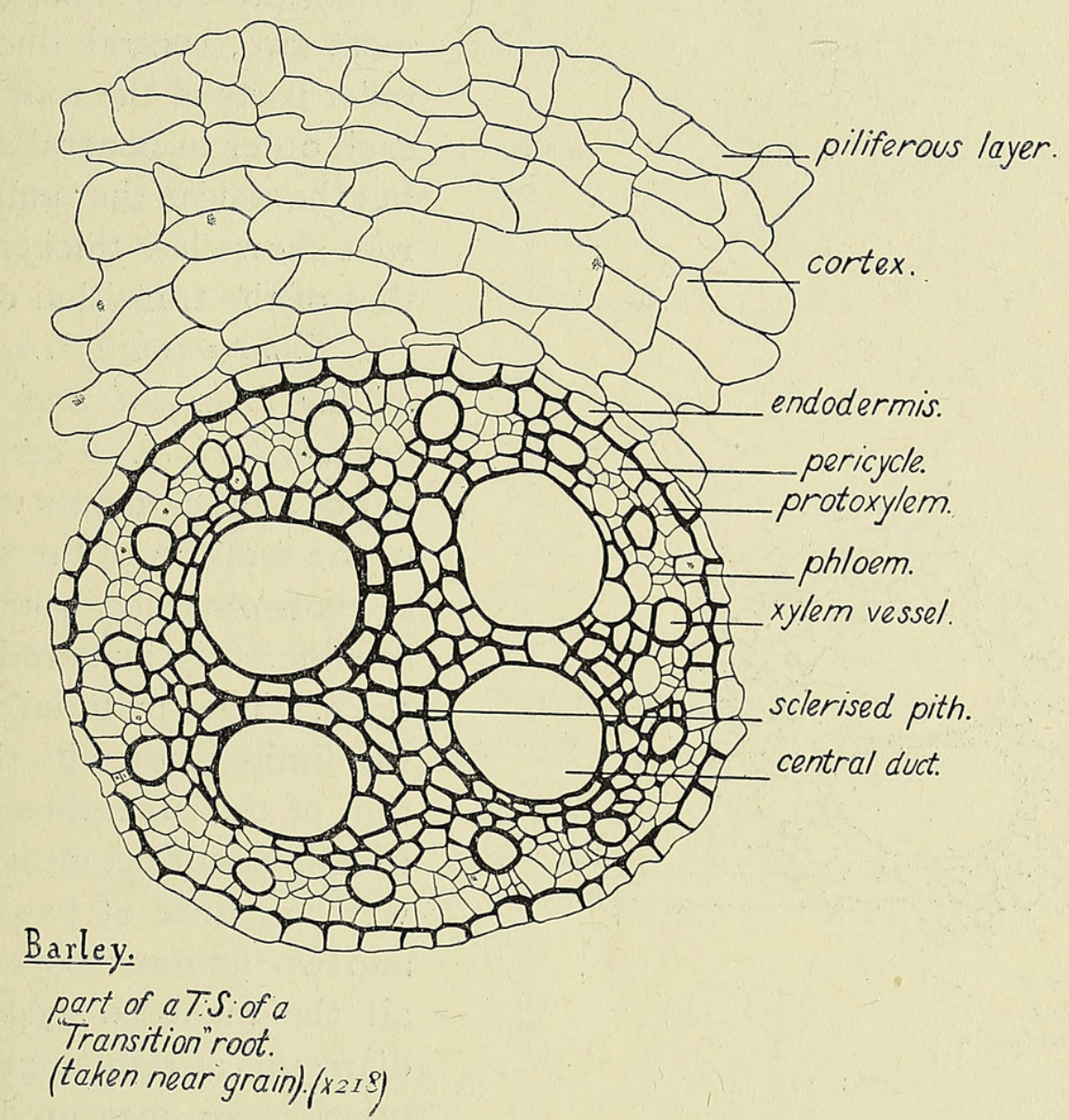

FIG. 10 .

The question then arises as to what happens to the newly formed parts of these transitional roots. Fig. II is drawn from a section taken near the tip of a root, which was obviously of the 'unbranched' type but carried a number of laterals. A section near the grain of this root shows essentially the same structure as that of Fig. IO, that is, there are five large central ducts and a considerable number of thickened cells in the stele, but here at the tip there are only two very large central ducts and the development of thickened tissue is still more marked. The phloem is also well differentiated and the pericycle and endodermis are thickened, especially in the zones between the xylem groups. In the water-culture material several roots 
were found in which a section near the grain shows five large ducts traversing a stele in which all the tissues are thickened, while near the roottip only one central space occurs in a stele of the type found in the young branched roots.

The outstanding differences between the typical 'unbranched' roots and the roots which were originally 'unbranched' but have assumed a branched habit is that in the former the young root shows the characteristic unthickened stele with its central region traversed by four to six ducts, while the latter possesses a stele with a considerable quantity of sclerized

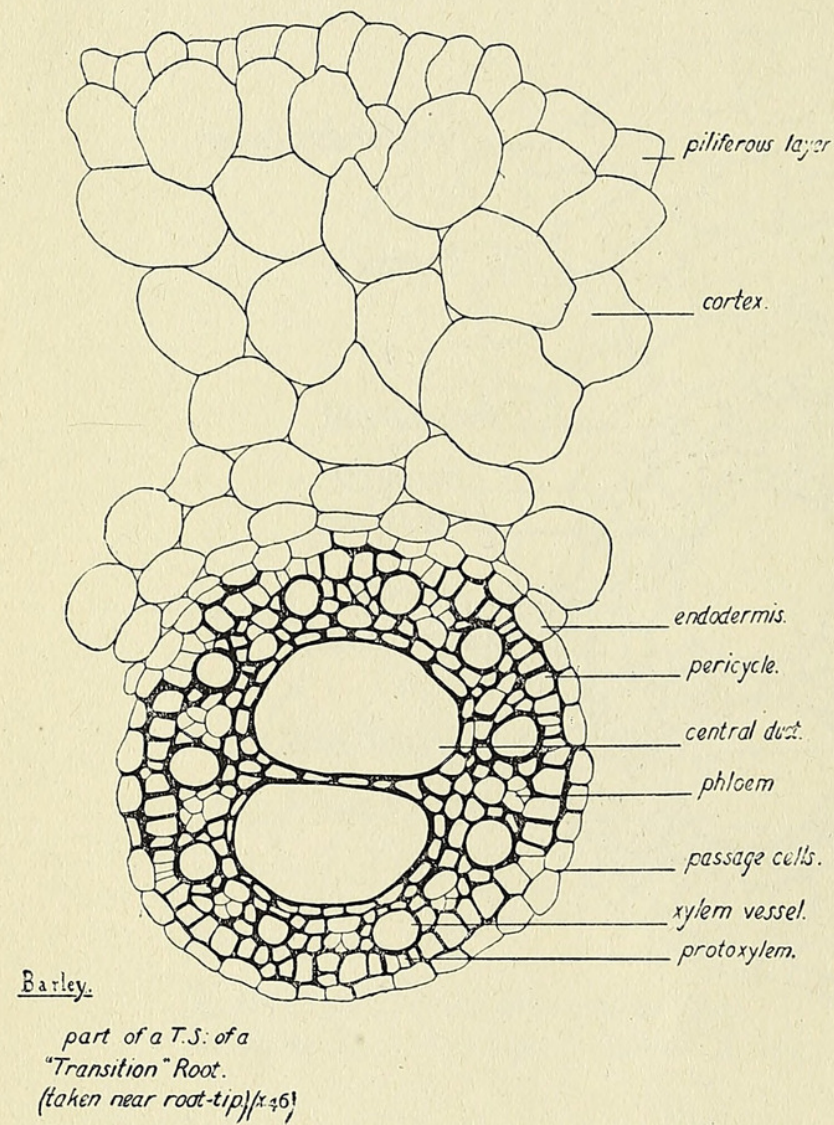

FIG. II. tissue and only one, or at the most two, central ducts. The older parts of the root resemble each other in general structure, but the stele of the ' unbranched' root shows less thickening than that of the transition root.

Comparison of the anatomy of the branched and the 'unbranched' roots. A certain number of measurements were made of the sections of the two types of roots obtained from five sets of differently manured pot cultures. The material available was limited, but, with the exception of the superphosphate and potash manuring, measurements were obtained of two branched and two 'unbranched' roots from all the manurial types. Two diameters at right angles to each other were measured for the whole root, the stele, and for the central duct or ducts. It must be remembered that, when this material was being preserved, it was not realized that the 'unbranched' roots ultimately resembled the branched type, so that in certain cases roots which were originally of the 'unbranched' type were preserved as typical branched roots. The measurements of these transition roots together with those of their corresponding true 'unbranched' roots are collected together in Table II, while in Table I are the measurements of the true branched and 'unbranched' types. It will be noticed that in both cases where originally 'unbranched' roots were taken as branched roots, the plants had been treated with superphosphate, and this is a manure which tends to hasten the formation of 'unbranched' roots, so that at 


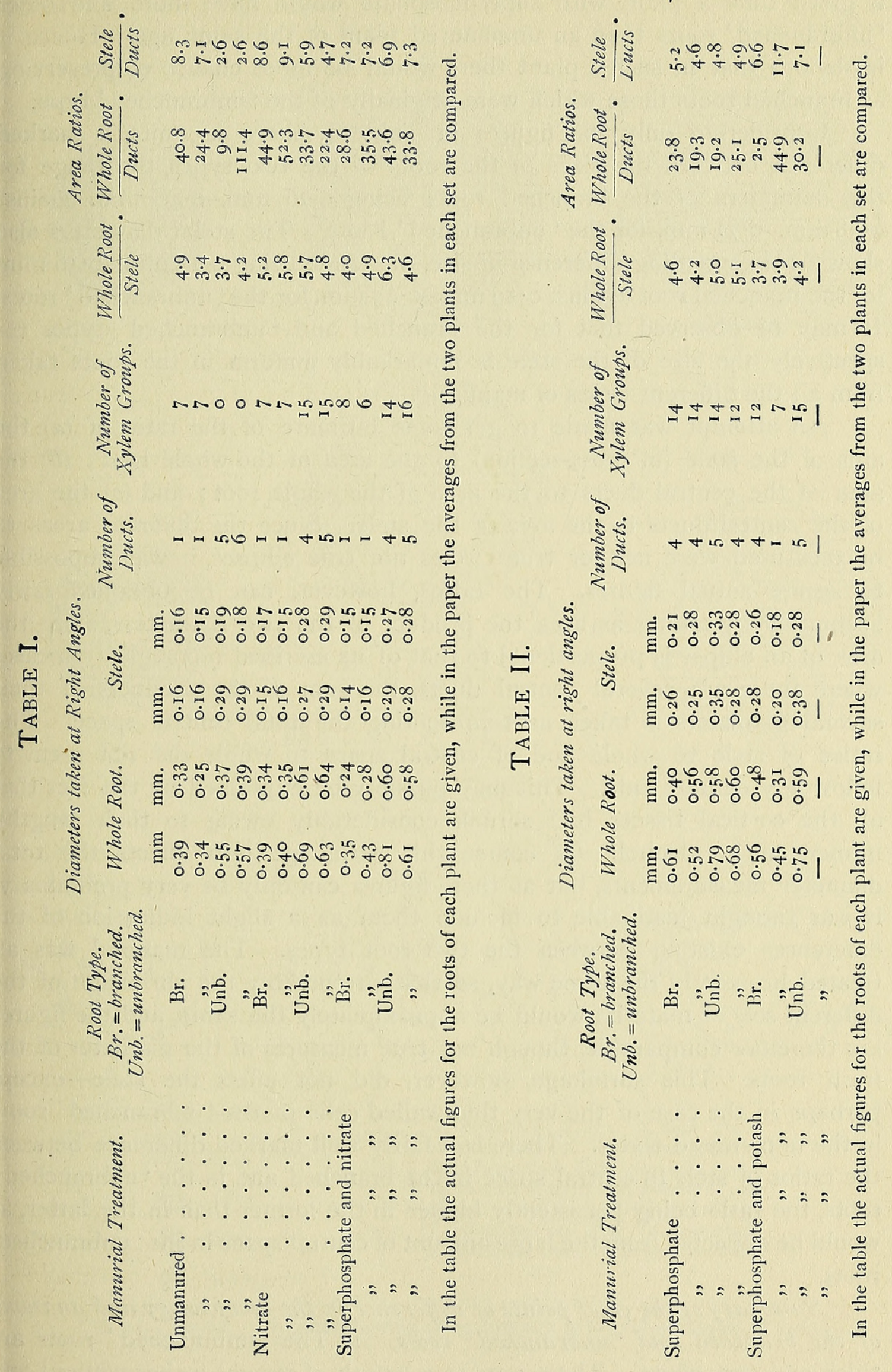


a given time a plant with superphosphate would have more and older ' unbranched' roots than an unmanured plant of the same age. Hence it is obvious that in such a plant there would be more chance of preserving as branched roots those which were originally of the 'unbranched' type.

Considering only the figures in Table $\mathrm{I}$, there is quite a marked difference between the sizes of the roots of the two types, the range for the diameters of the branched roots being $0.26 \mathrm{~mm} .-0.40 \mathrm{~mm}$. against $0.38 \mathrm{~mm} .-0.7 \mathrm{I} \mathrm{mm}$. for the 'unbranched' roots. The stelar diameters also show a corresponding difference in size, the range being $0.15 \mathrm{~mm}$.-0.16 $\mathrm{mm}$. for the branched root against $0.19 \mathrm{~mm}$. $-0.29 \mathrm{~mm}$. for the 'unbranched' roots. It may be observed that for the branched and 'unbranched' types respectively, the size of the stele is remarkably uniform in the roots taken from all the different types of manuring.

An attempt was made to get some estimate of the ratio of $(a)$ the area of the stele (in cross-section) to the area of the whole root; $(b)$ the area of the central ducts to the area of the whole root; and $(c)$ the area of the central ducts to the area of the stele. Since the different areas to be measured were neither true circles nor true ellipses, it was impossible to secure actual figures. The ratios, however, can be obtained fairly accurately by taking as area the product of the two diameters, since the area of an ellipse is proportional to that of its escribed rectangle. In cases where there are several central ducts, the sum of the products of their several diameters is taken as representing the total central space. The ratios of stele to whole and of central space to whole did not seem to follow any definite rule. This may possibly be explained by the fact that all the cortical tissues had shrunk considerably owing to their lengthy immersion in alcohol. Of course this shrinkage also affects the total diameter measurements, but as these figures can only be very preliminary, it was thought justifiable to include them as a slight indication of the differences existing between the two root types. The material was all treated in exactly the same way, so that presumably the shrinkage of the different sets of material would be approximately the same, and the figures are therefore comparable, though not true measures of the diameter of the fresh roots. This shrinkage, however, did not affect the stele-except perhaps in the case of the very thin-walled cells of the 'unbranched' roots in the unmanured series. There is a fairly well marked difference between the ratios of stele to central space in the branched and in the 'unbranched' roots, the ratio being persistently higher in the former than in the latter, as would be expected from the large amount of central space in the ' unbranched' roots.

Summary of the chief points of difference in the morphology and anatomy of the branched and 'unbranched' roots. I. The 'unbranched' roots are thick and very white. They grow to a length of several inches without any 
A.

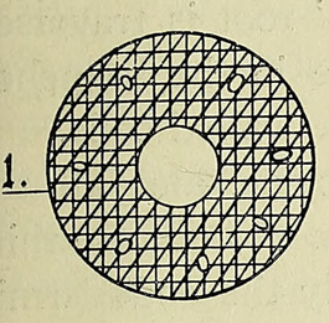

B.
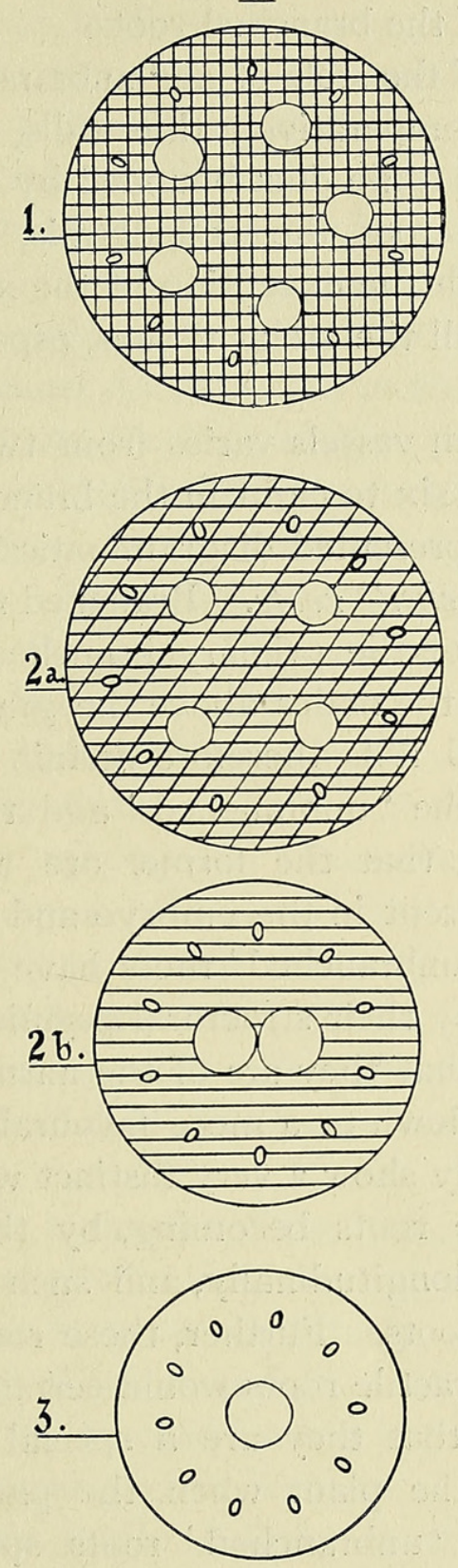

C.
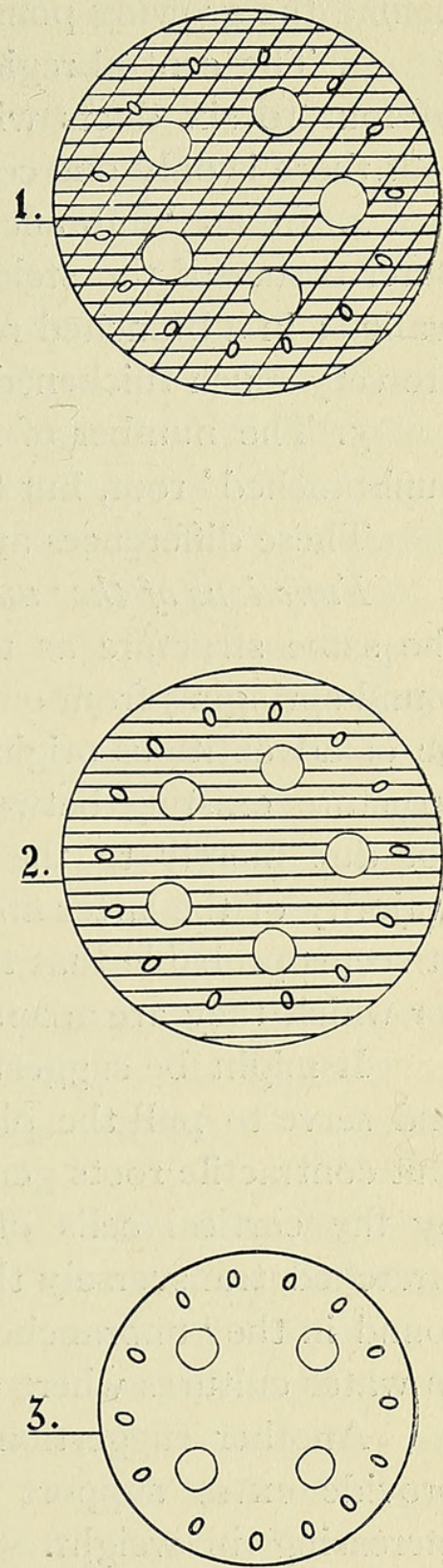

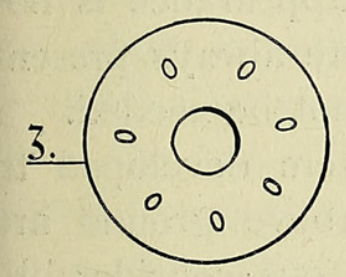

A. Branched Root. 1, near grain. 2 , middle of root. 3 , behind root-iip. B. 'Transition Root.' I, near grain. $2 a$, middle of root. $2 b$, middle of root nearer root-tip. 3 , behind root-tip. C. 'Unbranched' Root. I, near grain. 2 , middle of root. 3 , behind root-tip.

FIG. I2. Barley. Diagrams showing stelar structure of the different types of roots. 
laterals; the branched roots are thin and give off laterals when only an inch or two long.

2. Abundant root-hairs exist all along the 'unbranched' roots, but only behind the growing points of the branched roots.

3. The central region of the stele of an 'unbranched' root is traversed by four to six ducts with comparatively thin walls, while in the branched root there is only one central axile duct bounded by thick-walled cells.

4. In an 'unbranched' root the endodermis, pericycle, and all the outer tissues of the stele, with the exception of the xylem vessels, are thinwalled; in a branched root all the stelar tissues, especially the endodermis, are very much thickened.

5. The number of xylem vessels varies from twelve to sixteen in the ' unbranched' root, but from six to eight in the branched root.

These differences are represented diagrammatically in Fig. I2.

Functions of the 'unbranched' roots. Branched roots having identically the same structure as that of the primary branched roots are sometimes found springing from one of the nodes above the grain. Such a root must be of adventitious origin, and it is therefore certain that the differences in structure existing between the 'unbranched' and the branched roots are not due merely to the fact that the former are adventitious while the majority of the latter are present in the embryo and spring from the grain. It seems probable that the 'unbranched' roots have some special function for which they are adapted by their structural peculiarities.

It might be suggested that they are of the nature of contractile roots, and serve to pull the plant down to a more favourable position in the soil. But contractile roots generally show a very distinct wrinkled surface caused by the cortical cells of the roots becoming, by their turgescence, more stretched transversely than longitudinally, and such an appearance is not found in the 'unbranched' roots. Further, these roots are always present in water cultures where contractile roots would certainly not be needed.

Another suggestion is that they are a special system developed to provide extra support for the plant when the parts above ground are increasing in weight. The 'unbranched' roots spread out considerably and form a network just beneath the soil surface, so that they are in a position to give good support to the plant. They are then physiologically comparable with the stilt- or buttress-roots occurring in Pandamus, Rhizophora, \&c., and still more comparable with the adventitious roots which arise from the lower nodes of the stem of Zea Mais. Haberlandt, ${ }^{1}$ following Warming's description of the stilt-roots of Rhizophora Mangle, states that they are of a stem-like structure. The middle of each root is occupied by a large pith surrounded by alternating groups of xylem and phloem, while thick-walled mechanical cells are found on the medullary side of the water- 
conducting tissue. For the adventitious roots of Zea Mais Haberlandt describes a fibrovascular cylinder enclosing a wide core of pith surrounded by alternating groups of xylem and phloem. Very wide vessels disposed in a ring are conspicuous in the xylem groups, and the endodermis is thickwalled. Further, there is a zone of thick-walled parenchyma found in the cortex just within the piliferous layer. The 'unbranched' roots of barley certainly have a central pith, though traversed by ducts, but there is no development of thick-walled tissue to correspond to that found in both Rhizophora and Zea. On the other hand, farmers hold that if a horseharrow is used among cereals after the 'tillering' or 'unbranched ' roots are well established, the plants do not stand so well and are apt to lodge badly. If the 'unbranched' roots are to render support to the plant, then it would be expected that their mechanical tissues would be developed at least as much as, if not more than, those of the branched roots, since the latter certainly do support the plant. Some idea of the mechanical strength of a root is given by the ratio of the area of the stele to that of the central space. Referring to Table I, it is seen that in the unmanured and in the nitrate only plants this ratio is considerably higher for the branched than for the ' unbranched' roots, but in the superphosphate and nitrate plants the ratio is the same for both root types. Presumably then, in the last-named manurial series, the support offered by the 'unbranched' is equal to that offered by the branched root, and this may be significant in view of the fact that superphosphate manuring checks the lodging tendency which occurs in plants receiving only nitrogenous fertilizers. ${ }^{1}$ It is therefore probable that the 'unbranched ' roots do serve to some extent as 'buttress' or supporting roots.

Most probably the main use of the 'unbranched' roots is to be found in connexion with the plant's nutritive supply. The roots appear when the plant is beginning to grow vigorously, and consequently when it is needing a good supply of water and food which must be obtained chiefly from the soil. The 'unbranched' roots are so constructed that they are specially adapted to meet such a demand. They are invested with roothairs throughout their entire length, so that their absorptive area is considerably larger than it is in the branched roots, where absorption can only take place in the parts behind the growing root-tips, where the roothairs are still functioning. The number of large xylem vessels is increased, so that there are more passage-ways along which the water can travel with ease. The large ducts in the pith are also probably used for the translocation of water, while the unthickened condition of practically all the stelar tissues allows water to pass from cell to cell with considerable rapidity.

It may be suggested that the development of lateral branches in the

1 Purvis, O. N.: The Effect of Potassium Salts on the Anatomy of Dactylis glomerata. Journ. Agric. Sci., vol. ix, Part IV, Oct. I9I9, p. 339. 
'unbranched' roots is influenced by light, since these roots occasionally come up to the soil surface and are consequently nearer the light than are the branched roots. That this is not the case is clear from the fact that ultimately lateral branches are developed; moreover, Newton ${ }^{1}$ has shown that for terrestrial plants grown in water, branching takes place just as freely in the light as in the dark. The dormancy of the lateral branches is explained by the fact that the 'unbranched' roots develop when the plant is making vigorous growth and needs a plentiful supply of water with its dissolved nitrogenous and mineral constituents; if the roots were to produce laterals immediately, then thickening of the stelar tissue would follow and the translocation of water would become slower. On the other hand, when the laterals are dormant, the tissues of the stele remain comparatively thin-walled and water can very readily pass through the roots to the stem and leaves, and in addition the root-hairs are able to continue functioning along the whole length of the root.

The theory that the 'unbranched' roots are chiefly connected with the food-and water-supply of the plant receives further support from the fact that these roots are only formed during the early stages of the plant's vigorous growth. Researches on the development of root and shoot ${ }^{2}$ showed that the formation of ' unbranched' roots had entirely ceased by the time the plant had finished its vegetative growth and was entering on its reproductive phase. At this period of the plant's history the nitrogen and ash constituents are migrating steadily from the straw into the grain, ${ }^{3}$ so that there is no need for a large root-absorbing area. On the other hand, if the 'unbranched' roots functioned chiefly as buttress-roots, the plant would need them even more when the heavy grain is being formed, but that is just the time when their development ceases. Therefore the most probable function for the 'unbranched' roots is to ensure a good supply of water, \&c., when the plant is in a condition of strong vegetative growth.

\section{Summary.}

I. The root system of a well-developed barley plant consists of two types of roots: $(a)$ a thin branched type, and $(b)$ a thick 'unbranched' type, with very abundant root-hairs.

2. A branched root possesses a much-thickened stele with a single large axile vessel and six to eight xylem groups all bounded by a very thick-walled endodermis. In an 'unbranched' root neither the endodermis nor the stelar tissues are thickened, the xylem groups number from twelve to sixteen,

1 Newton, L. M. : Conditions which affect the Branching of Roots. Rept. Mich. Acad. Sci., Lansing, I9I I, xiii, p. 200.

2 Brenchley and Jackson: loc. cit.

3 Brenchley, W. E.: The Development of the Grain of Barley. Ann. Bot., vol. xxvi, No. ciii, July, I9I2, pp. 913-19. 
Fackson.-Anatomical Structure of the Roots of Barley. 39 and the middle of the root consists of thin-walled pith cells traversed by four to six ducts.

3. The chief function of the 'unbranched' roots is probably to provide the plant with a plentiful supply of water and its dissolved food, at the time when vigorous growth is setting in. This function is provided for by:

(a) abundant root-hairs;

(b) an increased number of large vessels and central ducts;

(c) the existence of a stele composed almost entirely of thin-walled elements.

In conclusion I wish to express my thanks to Dr. W. E. Brenchley for her very helpful and ever-ready advice throughout the whole of this work. 


\section{$2 \mathrm{BHL}$ Biodiversity Heritage Library}

Jackson, Violet G. 1922. "Anatomical structure of the roots of barley." Annals of botany 36, 21-39. https://doi.org/10.1093/oxfordjournals.aob.a089785.

View This Item Online: https://www.biodiversitylibrary.org/item/234428

DOI: https://doi.org/10.1093/oxfordjournals.aob.a089785

Permalink: https://www.biodiversitylibrary.org/partpdf/319025

\section{Holding Institution}

Smithsonian Libraries

\section{Sponsored by}

Biodiversity Heritage Library

\section{Copyright \& Reuse}

Copyright Status: Not in copyright. The BHL knows of no copyright restrictions on this item.

This document was created from content at the Biodiversity Heritage Library, the world's largest open access digital library for biodiversity literature and archives. Visit BHL at https://www.biodiversitylibrary.org. 